\title{
北海道で発想の転換を 地球温暖化という大ピンチを新たなビジネスチャンス到来と考えることはできないだろうか?
}

Change your conception at Hokkaido! Crisis of earth-warming can be considered to be a new business chance.

西 村 紳一郎

数年前あたりから北海道でも大型の台風がしばしば大暴 れして大きな被害を与え始めている。北大の大きな観光資 源でもある「ポプラ並木」が一昨年受けた壊滅的な惨状は 北大の関係者に留まらず札幌市民や多くの観光客に大きな ショックを与えたのがまだ記憶に新しい。台風は北海道に 来るころには温帯低気圧になってしまうという常識が通用 しなくなってきた。地球温暖化の具体的な影響を身近に感 じることが本当に多くなったように思う。北国出身の田舎 者である小生にとって、ほとんど亜熱帯と化したこの時期 の東京・大阪方面(むしろ南日本とでも言うべきか?)への 出張は益々しんどい状況になってきた。新聞記事などでも この温暖化問題に関連する話題の取り上げられる機会がか なり増してきたのではないだろうか? シジリアの凍土が融 け始めてマンモスの化石がごろごろと地表付近で発見され たり、北極の水山が融けて崩壊したり小さくなって流れ出 したため北極グマの家族が棲みかを失ってしまったりと、 北海道以北での顕著な現象もさることながらマラリアを媒 介すると言われる蚊がじわじわ日本へ北上しているという 深刻な現実に接してみるとそろそろ他人ごとではすまされ ないでと思い始めた人々も少なくないはずである。

私達のグループで取り組んできた酵素反応を基本とする 糖鎖自動合成法に関する研究が幸運にも昨年度の GSC (Green Sustainable Chemistry)賞・経済産業大臣賞に選出 されるという予想もしなかった名誉な「大事件」に遭遇し てみて、改めてわれわれ化学を糧としているものに課せら れた新しい使命の重さを痛感するようになった。繊維産業 にも深く関係する多くの化学・化学工業企業と関連学協会 等が体系的な GSC 活動を熱心に進めてグリーンケミスト リーを実践することを目的とした多くの立派な研究を支援 してきたことやエネルギー・資源、地球環境問題を含めた 総合的な「温暖化対策」に真剣に取り組んでいることを知 り深く感銘した次第である。特にこのような地道な活動を

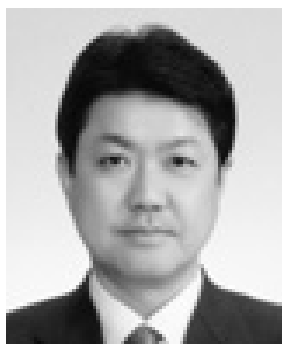

SHINICHIRO NISHIMURA

北海道大学大学院先端生命科学研究院 先端生命科学部門·先端生体制御科学分 野

〈専門〉生命有機化学・高分子化学・糖 鎖工学・創薬化学

〈趣味〉野球
通して研究者や技術者の予備軍とでも言うべき次代を担う 若い世代に向けた啓蒙活動の重要性は極めて大きい。すな わち、これからは研究開発の初期の段階から「グリーン貢 献度」とでも言うべき視点が必要になるのだという一種の 無意識のモラルとバランス感覚を学生時代に徹底的に吒き 込んでおけげ、効率性と利潤追求を最優先させてきた前世 紀の価值観が、少なくともその学生たちが主役となった次 世代の研究者・技術者からは全く支持されなくなる筈であ る。コストや性能、安全性に加えて、原料の調達法や生産 工程等における「グリーン貢献度」を製品の総合的な価值 を評価する指標に加えるべきであり、また、これらの指標 を含めた新たな国際標準に基づく新しいルール作りを加速 させるべきだと思う。

また、一方に打いて大学や公的研究機関の化学者は温暖 化という大きな課題を解決するためにそれぞれがもっと知 恵を絞って真剣に考えなければならない。化学に関連する 学科・大学院組織では「グリーン化学」という新領域の教 育メニューを積極的に導入して地球規模の温暖化が人間社 会や自然界にどのような影響を与えているのかという基本 的な事項を系統的に教育する必要がある。そうすれば近い 将来、彼らがきっと「どのような新素材をどのようにして 構築すれば良いのか」という難問に対する答えを導いてく れるに違いない。日本の化学者にはピンチを新たなビジネ スチャンスに変えるしたたかさと実力が充分あると信じた いが、次世代のインキュベーションによる「持続的挑戦」 というセンスが久如していることを否定できない。

知床が世界自然遺産のひとつに登録された。山々の豊か な緑は $\mathrm{CO}_{2}$ と $\mathrm{H}_{2} \mathrm{O}$ を原料に大量の炭水化物をクリーンな 光合成プロセスで絶えず生産し続けている。我々もこの北 海道で地球に優しい次世代の化学を探求する試みに挑戦し てみようと思う。札幌で本年 9 月に開催される繊維学会夏 季セミナーではナノファイバーや再生医療等のテーマを取 り上げ新材料と未来医療という先端異分野融合の可能性に ついて議論することが予定されている。繊維科学・工業の 新たな挑戦への第一歩となることを期待したい。 